\title{
Walking with Death. Two Short Stories by Óscar Collazos: The Sleeping Car and Somebody Is Knocking on the Door
}

\section{De la mano de la muerte. Dos cuentos de Óscar Collazos: Soledad al final del coche cama y Alguien llama a mi puerta}

\section{Manuel Cortés Castañeda ${ }^{1}$}

The great majority of literary critics who have analyzed the short stories and novels written by the Colombian author Óscar Collazos have fallen into the trap of subjugating the text to rigid preconceived ideas. In general, they have read his work following what others have already said about these writings, forcing the narrative into analytical structures that obscure the text rather than illuminate it. With few exceptions, critics categorize Collazos's literary work as simple, unadorned realism. They affirm that it merely mirrors the reality of the Colombian social, political, and cultural conflicts; it is little more than a narrative inventory of situations, characters or conflicts. Nobody has noticed, however, that it is precisely because this author's texts are so deeply connected to reality that his art is able to transcend it. All his texts are the result of a language which becomes even stranger and more absurd when it tries (and fails) to capture the essence of reality. The realism in Collazos is not a simple recounting of situations and conflicts, but a chronicle of horror, death and destruction, as well as the effective reaffirmation of the absurd. In this essay, entitled Walking with Death. Two Short Stories by Óscar Collazos: "The Sleeping Car" and "Somebody Is Knocking on the Door", I will analyze two of his short stories and throughout these texts I will try to demonstrate that his writings, while deeply connected to the social and political conflicts of Colombian society, are also more widely connected to the fantastic literature "tradition" which includes so many important writers in Latin America. Like them, Collazos's literary work is always in contradiction with reality, criticizing it rather than naïvely portraying it. [Article copies available for a fee from The Transformative Studies Institute. E-mail address: journal@transformativestudies.org Website: http://www.transformativestudies.org (C2019 by The Transformative Studies Institute. All rights reserved.]

KEYWORDS: Death, Solitude, Anguish, Desperation, Emptiness, Absurdity, Confusion, Failure, Contradiction, Paradox.

\footnotetext{
1 Manuel Cortés Castañeda. Biography available at end of article. Address correspondence to: Manuel Cortés Castañeda; e-mail: Manuel.CortesCastaneda@eku.edu.
} 